\title{
ANALISIS PENENTUAN KEPENTINGAN JALAN POROS KABUPATEN ANTAR KECAMATAN DI KABUPATEN TRENGGALEK UNTUK MENDUKUNG PENGEMBANGAN WILAYAH
}

\author{
Catur Widiasmoro ${ }^{a}$, Hitapriya Suprayitno ${ }^{\mathrm{b}}$ dan Eko Budi Santosoc
}

\begin{abstract}
Infrastructure has a very important role as certain to instigates economic growth and regional development. Transportation serves facility for production and investment systems that enables regional services and activities. Region developed on potential itself, to support it how determines best alternative of road links is required. To obtain weight of criteria in this research using pairwise comparison, and furthermore the Technique for Order Preference by Similarity to Ideal Solution is used to discover preference value from each road links. This research indicates that preference inter-districts road Bendo-Surodakan is the main priority with value of preference 3,07, then Suruh-Pule, Gandusari-Kampak road link with score 2,44 and 2,30, consecutively. Road link with lowest score obtained by Bangunsari-Bulu as 0,057
\end{abstract}

Keywords: road infrastructure, inter-district road priority, regional development, pairwise comparison, Technique for Order Preference by Similarity to Ideal Solution

Abstrak: Infrastruktur memiliki peran yang sangat penting sebagai penggerak pertumbuhan ekonomi dan pembangunan wilayah. Transportasi berperan sebagai fasilitas bagi sistem produksi dan investasi yang memberikan dampak positif bagi pelayanan dan pendorong aktivitas wilayah. Wilayah dikembangkan berdasarkan potensi-potensi yang ada, untuk mendukungnya maka jaringan jalan harus disusun prioritas terkait peran dalam perkembangan wilayah. Metode yang digunakan dalam penelitian ini yaitu: pairwise comparison untuk mendapatkan bobot kriteria; dan Technique for Order Preference by Similarity to Ideal Solution untuk menentukan nilai preferensi masing-masing ruas. Penelitian ini menghasilkan ruas Bendo-Surodakan sebagai prioritas pertama dengan nilai preferensi 3,07, kemudian ruas Suruh-Pule dengan nilai preferensi 2,44, ruas Gandusari-Kampak pada urutan ketiga dengan nilai preferensi ruas 2,30, sedangkan ruas Bangunsari-Bulu pada urutan terakhir dengan nilai preferensi ruas 0,057.

Kata Kunci : infrastruktur jalan, prioritas jalan poros antar kecamatan, pengembangan wilayah, perbandingan berpasangan, Technique for Order Preference by Similarity to Ideal Solution.

\section{PENDAHULUAN}

Untuk mendukung sistem kegiatan di wilayah maka infrastruktur jalan sangat strategis bagi sebuah sistem transportasi. Jaringan jalan akan membentuk kesatuan ruang bagi wilayah yang terjadi melalui adanya pola interaksi spasial sistem transportasi antar pusat-pusat yang ada pada suatu wilayah [1]. Pengembangan wilayah merupakan rangkaian upaya untuk mewujudkan keterpaduan dalam penggunaan berbagai sumber daya dalam rangka pencapaian tujuan pembangunan yang berbasiskan pada produktivitas, keadilan dan berkelanjutan [2]. )

Penentuan prioritas merupakan proses untuk menyusun rangking terhadap sekelompok alternatif, salah satu Multi Criteria Decision Making (MCDM) yang umumnya digunakan dalam prioritisasi masalah adalah menggunakan Analytical Hierarchy Process (AHP). [3] Metode AHP sangat bergantung terhadap kuantifikasi

aStudent in the Department of Civil Engineering, Institut Teknologi Sepuluh Nopember, ITS Campus, Sukolilo, Surabaya 60111, Indonesia. Email: tjatoer.asmo@gmail.com

${ }^{b}$ Lecturer in the Department of Civil Engineering, Institut Teknologi Sepuluh Nopember, ITS Campus, Sukolilo, Surabaya 60111, Indonesia Email: suprayitno.hita@gmail.com

${ }^{c}$ Lecturer in the Department of Urban and Regional Planning, Institut Teknologi Sepuluh Nopember, ITS Campus, Sukolilo, Surabaya 60111, Indonesia. Email: eko_budi@urplan.its.ac.id

Note. The manuscript for this paper was submitted for review and possible publication on January 09, 2018. This paper is part of the ITS Journal of Civil Engineering, Vol. 33, No. 2, November 2018. (C) ITS Journal of Civil Engineering, ISSN 2579-9029/2017. penilaian pihak pengambil keputusan, dan dalam prosesnya kuantifikasi alternatif terjadi bias, maka dalam penelitian ini untuk penentuan rangking alternatif digunakan metode Technique for Order Preference by Similarity to Ideal Solution (TOPSIS).

Tujuan penelitian ini adalah mendapatkan prioritas ruas jalan poros antar kecamatan yang menghubungkan antar simpul pusat kegiatan wilayah, sesuai pendapat stakeholder dan data eksisting yang ada. Masalah dalam penelitian ini, adalah: bagaimana kriteria-kriteria yang dapat mempengaruhi keputusan pembina jalan untuk pengembangan wilayah, bagaimana bobot kepentingan antar kriteria berdasarkan pembuat keputusan di Kabupaten Trenggalek, bagaimana nilai eksisting masingmasing alternatif ruas jalan berdasarkan penilaian kriteria, dan bagaimana urutan prioritas jalan yang memiliki dampak strategis terhadap perkembangan wilayah.

\section{METODA PENELITIAN}

Pengumpulan data primer dilakukan melalui metode wawancara, penyebaran kuesioner, dan observasi langsung di lapangan. Responden dalam penelitian ini terdiri dari 8 (delapan) orang, adalah: Kepala Bappeda; Kepala Dinas PU Bina Marga; Kabid Pembangunan dan Pemeliharaan Jalan dan Jembatan; Kabid Fisik dan Prasarana; Kabid Perhubungan; Kasubbid Pemeliharaan Jalan dan Jembatan; Kasubbid Perencanaan Teknis Jalan; dan Kasubbid Tata Ruang Wilayah. Untuk mendapatkan data kondisi eksisting atas kriteria diperoleh dari data sekunder yang diperoleh dari Badan Pusat Statistik, Bappeda, Dinas Pekerjaan Umum Bina Marga, Dinas Perhubungan, Badan Pemberdayaan Masyarakat dan 
Pemerintahan Desa, Dinas Pendidikan dan Dinas Kesehatan Kabupaten Trenggalek.

Tahapan pengolahan data dalam penelitian ini dilakukan dengan 4 (empat) tahapan sebagai berikut: deskriptif dari hasil wawancara dengan para responden pembina jalan kabupaten di Trenggalek untuk menilai kesesuaian kriteria yang diperoleh dari kajian pustaka dengan kondisi pengelolaan jalan kabupaten di lapangan; penentuan bobot antar kriteria; penentuan nilai kriteria pada masing-masing ruas; mencari nilai preferensi pada masing-masing ruas.

\section{ANALISIS DAN PEMBAHASAN}

\section{Obyek Penelitian}

Jaringan jalan yang diteliti adalah ruas-ruas jalan poros antar kecamatan yang menghubungkan simpulsimpul jasa distribusi tingkat lokal pada tingkat kabupaten yang dihubungkan oleh jalan lokal primer yang menghubungkan ibukota kabupaten dengan ibukota kecamatan dan ibukota kecamatan dengan ibukota kecamatan. Ruas jalan yang diteliti pada Tabel 1 .

Tabel 1. Ruas Jalan Poros Antar Kecamatan

\begin{tabular}{clcl}
\hline No. & \multicolumn{1}{c}{ Nama Ruas } & No. & \multicolumn{1}{c}{ Nama Ruas } \\
\hline 1. & Kedunglurah - & 7. & Bendo - Surodakan \\
\hline 2. & Gandusari - Kampak & 8. & Ngetal - Gandusari \\
\hline 3. & Kampak - Munjungan & 9. & Sumberingin - \\
\hline 4. & Ngares - Bendungan & 10. & Pringapus -Bogoran \\
\hline 5. & Nglongsor - Karangan & 11. & Bangunsari - Bulu \\
\hline 6. & Suruh - Pule & & \\
\hline
\end{tabular}

Gambar 1 merupakan ruas-ruas jalan yang diteliti, yang merupakan jalan strategis kabupaten merupakan poros antar kecamatan yang terhubung dengan jalan nasional pada wilayah Kabupaten Trenggalek.

\section{Pemilihan Kriteria yang Digunakan}

Aspek ekonomi dalam pengelolaan jalan, kriteria yang diperoleh adalah: biaya peningkatan jalan, potensi ekonomi wilayah, lalu lintas harian rata-rata, pertumbuhan ekonomi, dan hirarki jalan. Aspek sosial yang diperoleh adalah: jumlah penduduk, dukungan jalan

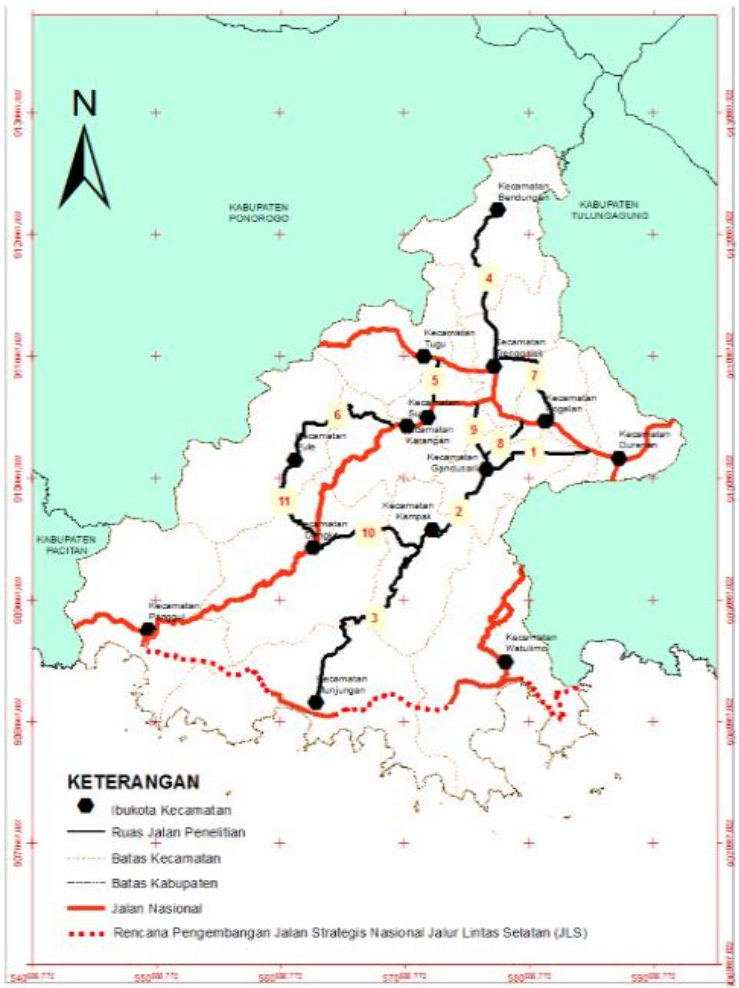

Gambar 1. Ruas Jalan Poros Antar Kecamatan

terhadap fasilitas, dan kenyamanan jalan. Aspek lingkungan kriterianya adalah kondisi jalan, kelestarian kawasan lindung, dan luas daerah pelayanan. Kriteria ditentukan dengan mempertimbangkan aspek nilai skoring kriteria. Nilai batas (NB) kriteria, dirumuskan sebagai berikut.

$$
\mathrm{NB}=\frac{\mathrm{Nmax}-\mathrm{Nmin}}{2}
$$

Keterangan :

$$
\begin{aligned}
& \mathrm{NB}=\text { Nilai batas skor kriteria } \\
& \mathrm{Nmax}=\quad \text { Nilai maximum skor kriteria } \\
& \mathrm{Nmin}=\quad \text { Nilai minimum } \text { skor kriteria }
\end{aligned}
$$

Rekapitulasi penilaian responden ditunjukkan

\begin{tabular}{|c|c|c|c|c|c|c|c|c|c|}
\hline \multirow{2}{*}{ No. } & \multirow{2}{*}{ Kriteria } & \multicolumn{2}{|c|}{$\begin{array}{c}\text { Tidak } \\
\text { Penting } \\
\end{array}$} & \multicolumn{2}{|c|}{ Penting } & \multicolumn{2}{|c|}{$\begin{array}{l}\text { Sangat } \\
\text { Penting } \\
\end{array}$} & \multirow{2}{*}{$\begin{array}{l}\text { total } \\
\text { skor }\end{array}$} & \multirow{2}{*}{$\begin{array}{c}\text { Skor } \\
\text { rata- } \\
\text { rata }\end{array}$} \\
\hline & & j1 & skor & j2 & skor & j3 & skor & & \\
\hline 1 & Biaya penanganan jalan & 2 & 1 & 4 & 2 & 2 & 3 & 16 & 2 \\
\hline 2 & Potensi ekonomi wilayah & 1 & 1 & 2 & 2 & 5 & 3 & 20 & 2,5 \\
\hline 3 & Lalu lintas harian rata-rata & 0 & 1 & 1 & 2 & 7 & 3 & 23 & 2,875 \\
\hline 4 & Pertumbuhan ekonomi & 3 & 1 & 3 & 2 & 2 & 3 & 15 & 1,875 \\
\hline 5 & Hirarki jalan & 1 & 1 & 4 & 2 & 3 & 3 & 18 & 2,25 \\
\hline 6 & Jumlah penduduk & 0 & 1 & 2 & 2 & 6 & 3 & 22 & 2,75 \\
\hline 7 & Dukungan jalan terhadap fasilitas & 0 & 1 & 3 & 2 & 5 & 3 & 21 & 2,625 \\
\hline 8 & Kenyamanan pengguna & 5 & 1 & 2 & 2 & 1 & 3 & 12 & 1,5 \\
\hline 9 & Kondisi jalan & 0 & 1 & 1 & 2 & 7 & 3 & 23 & 2,875 \\
\hline 10 & Kelestarian kawasan lindung & 4 & 1 & 3 & 2 & 1 & 3 & 13 & 1,625 \\
\hline 11 & Luas daerah pelayanan. & 4 & 1 & 3 & 2 & 1 & 3 & 13 & 1,625 \\
\hline
\end{tabular}
dalam Tabel 2. Berdasar pada Tabel 2 diperoleh nilai batas 2,1875, sehingga menghasilkan kriteria potensi

Tabel 2. Rekapitulasi Penilaian Responden Atas Kriteria 
ekonomi wilayah, lalu lintas harian rata-rata, jumlah penduduk, fasilitas, hirarki ruas dan kondisi ruas jalan dan setelah dilakukan wawancara mendalam maka kriteria di atas dijadikan variabel penelitian.

\section{Pembobotan Kriteria}

Kuesioner yang disebarkan kepada responden menghasilkan bobot kepentingan atas kriteria yang dipasangkan. Bobot kepentingan antar kriteria diperoleh dari proses matriks perbandingan berpasangan antar kriteria. Bobot antar kriteria disajikan pada Tabel 3.

Tabel 3. Bobot Antar Kriteria

\begin{tabular}{clc}
\hline No. & \multicolumn{1}{c}{ Kriteria } & Bobot \\
\hline 1. & Potensi Ekonomi Wilayah & 0,2017 \\
\hline 2. & Lalu lintas Harian Rata-rata & 0,2406 \\
\hline 3. & Jumlah Penduduk & 0,0914 \\
\hline 4. & Fasilitas & 0,0393 \\
\hline 5. & Hirarki ruas & 0,0468 \\
\hline 6. & Kondisi ruas & 0,3802 \\
\hline
\end{tabular}

\section{Penilaian Kriteria}

Penilaian kondisi eksisting kriteria pada masingmasing ruas ini diperoleh berdasarkan data sekunder, dan data primer yang didapatkan dari dinas terkait maupun melalui wawancara.

Potensi Ekonomi Wilayah

Data kriteria potensi ekonomi wilayah didapatkan dengan langkah dijelaskan sebagai berikut, langkah awal adalah mendapatkan data sebaran komoditas unggulan pada wilayah yang dihubungkan oleh ruas yang diteliti, sebagaimana pada Tabel 4.

Sebaran komoditas unggulan kabupaten pada wilayah-wilayah yang didukung oleh ruas jalan yang diteliti kemudian didapatkan Tabel 5 yang menerangkan matriks konektivitas asal-tujuan dari distribusi komoditas.

Tabel 4. Sebaran Komoditas Wilayah di Ruas Jalan Kajian

\begin{tabular}{|c|c|c|c|c|c|c|c|c|c|c|}
\hline & & \multicolumn{9}{|c|}{ Komoditas (Ton/Ekor/Buah) } \\
\hline & & Padi & Jagung & $\begin{array}{c}\text { Ubi } \\
\text { Kayu }\end{array}$ & Kopi & Kelapa & $\begin{array}{c}\text { Ayam } \\
\text { Potong }\end{array}$ & Kambing & Sapi & $\begin{array}{c}\text { Perikanan } \\
\text { Laut }\end{array}$ \\
\hline \multirow{8}{*}{ 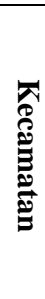 } & Gandusari & 16.088 & 8.230 & 34.285 & 8 & 182 & 543.032 & 16.034 & 1.978 & 0 \\
\hline & Kampak & 5.680 & 1.205 & 13.853 & 26 & 380 & 932.844 & 24.281 & 1.390 & 0 \\
\hline & Munjungan & 17.220 & 899 & 3.331 & 96 & 1.152 & 4.980 & 16.820 & 632 & 238 \\
\hline & Bendungan & 7.472 & 10.573 & 16.628 & 16 & 334 & 0 & 23.374 & 4.794 & 0 \\
\hline & Tugu & 10.955 & 17.213 & 51.548 & 5 & 1.396 & 21.180 & 18.141 & 4.048 & 0 \\
\hline & Pule & 9.157 & 9.378 & 69.956 & 23 & 421 & 34.176 & 88.808 & 3.016 & 0 \\
\hline & Pogalan & 14.619 & 3.961 & 2.544 & 0 & 28 & 17.140 & 11.239 & 2.423 & 0 \\
\hline & Karangan & 17.400 & 5.248 & 20.156 & 21 & 1.348 & 287.188 & 15.490 & 3.198 & 0 \\
\hline
\end{tabular}

Tabel 5. Matriks Pergerakan

\begin{tabular}{|c|c|c|c|c|c|c|c|c|c|c|c|c|}
\hline \multirow[b]{3}{*}{ Asal } & \multirow[b]{3}{*}{ Tujuan } & \multicolumn{11}{|c|}{.Tabel 5. Matriks Pergerakan } \\
\hline & & \multicolumn{11}{|c|}{$\begin{array}{c}\text { Ruas yang dilalui } \\
\text { jalan poros antar kecamatan }\end{array}$} \\
\hline & & 1 & 2 & 3 & 4 & 5 & 6 & 7 & 8 & 9 & 10 & 11 \\
\hline \multirow[t]{4}{*}{ Gandusari } & Trenggalek & - & - & - & - & - & - & - & 1 & 1 & - & - \\
\hline & Tulungagung & 1 & - & - & - & - & - & - & - & - & - & - \\
\hline & Pacitan & - & 1 & - & - & - & - & - & - & - & 1 & - \\
\hline & Ponorogo & - & - & - & - & 1 & - & - & - & 1 & - & - \\
\hline \multirow[t]{4}{*}{ Kampak } & Trenggalek & - & 1 & - & - & - & - & - & 1 & 1 & - & - \\
\hline & Tulungagung & 1 & 1 & - & - & - & - & - & - & - & - & - \\
\hline & Pacitan & - & - & - & - & - & - & - & - & - & 1 & - \\
\hline & Ponorogo & - & 1 & - & - & 1 & - & - & - & 1 & - & - \\
\hline \multirow[t]{4}{*}{ Munjungan } & Trenggalek & - & 1 & 1 & - & - & - & - & 1 & 1 & - & - \\
\hline & Tulungagung & 1 & 1 & 1 & - & - & - & - & - & - & - & - \\
\hline & Pacitan & - & - & - & - & - & - & - & - & - & - & - \\
\hline & Ponorogo & - & 1 & 1 & - & 1 & - & - & - & 1 & - & - \\
\hline \multirow[t]{4}{*}{ Bendungan } & Trenggalek & - & - & - & 1 & - & - & - & - & - & - & - \\
\hline & Tulungagung & - & - & - & 1 & - & - & 1 & - & - & - & - \\
\hline & Pacitan & - & - & - & 1 & - & - & - & - & - & - & - \\
\hline & Ponorogo & - & - & - & 1 & - & - & - & - & - & - & - \\
\hline \multirow[t]{4}{*}{ Tugu } & Trenggalek & - & - & - & - & - & - & - & - & - & - & - \\
\hline & Tulungagung & - & - & - & - & - & - & 1 & - & - & - & - \\
\hline & Pacitan & - & - & - & - & 1 & - & - & - & - & - & - \\
\hline & Ponorogo & - & - & - & - & - & - & - & - & - & - & - \\
\hline \multirow[t]{4}{*}{ Pule } & Trenggalek & - & - & - & - & - & 1 & - & - & - & - & - \\
\hline & Tulungagung & - & - & - & - & - & 1 & - & - & - & - & - \\
\hline & Pacitan & - & - & - & - & - & - & - & - & - & - & 1 \\
\hline & Ponorogo & - & - & - & - & - & 1 & - & - & - & - & - \\
\hline \multirow[t]{4}{*}{ Pogalan } & Trenggalek & - & - & - & - & - & - & 1 & - & - & - & - \\
\hline & Tulungagung & - & - & - & - & - & - & - & - & - & - & - \\
\hline & Pacitan & - & - & - & - & - & - & - & - & - & - & - \\
\hline & Ponorogo & - & - & - & - & - & - & 1 & - & - & - & - \\
\hline \multirow[t]{4}{*}{ Karangan } & Trenggalek & - & - & - & - & - & - & - & - & - & - & - \\
\hline & Tulungagung & - & - & - & - & - & - & - & - & - & - & - \\
\hline & Pacitan & - & - & - & - & - & - & - & - & - & - & - \\
\hline & Ponorogo & - & - & - & - & 1 & - & - & - & - & - & - \\
\hline
\end{tabular}


Tabel 6. Dukungan Ruas Jalan terhadap Komoditas Padi

\begin{tabular}{|c|c|c|c|c|c|c|c|c|c|c|c|c|}
\hline \multirow[b]{2}{*}{ Asal } & \multirow[b]{2}{*}{ Tujuan } & \multicolumn{11}{|c|}{ Dukungan ruas terhadap komoditas padi } \\
\hline & & 1 & 2 & 3 & 4 & 5 & 6 & 7 & 8 & 9 & 10 & 11 \\
\hline \multirow[t]{4}{*}{ Gandusari } & Trenggalek & - & - & - & - & - & - & - & 7.240 & 7.240 & - & - \\
\hline & Tulungagung & 3.218 & - & - & - & - & - & - & - & - & - & - \\
\hline & Pacitan & - & 1.609 & - & - & - & - & - & - & - & 1.609 & - \\
\hline & Ponorogo & - & - & - & - & 1.609 & - & - & - & 1.609 & - & - \\
\hline \multirow[t]{4}{*}{ Kampak } & Trenggalek & - & 2.272 & - & - & - & - & - & 2.272 & 2.272 & - & - \\
\hline & Tulungagung & 852 & 852 & - & - & - & - & - & - & - & - & - \\
\hline & Pacitan & - & - & - & - & - & - & - & - & - & 568 & - \\
\hline & Ponorogo & - & 1.136 & - & - & 1.136 & - & - & - & 1.136 & - & - \\
\hline \multirow[t]{4}{*}{ Munjungan } & Trenggalek & - & 6.027 & 6.027 & - & - & - & - & 6.027 & 6.027 & - & - \\
\hline & Tulungagung & 3.444 & 3.444 & 3.444 & - & - & - & - & - & - & - & - \\
\hline & Pacitan & - & - & - & - & - & - & - & - & - & - & - \\
\hline & Ponorogo & - & 1.722 & 1.722 & - & 1.722 & - & - & - & 1.722 & - & - \\
\hline \multirow[t]{4}{*}{ Bendungan } & Trenggalek & - & - & - & 3.362 & - & - & - & - & - & - & - \\
\hline & Tulungagung & - & - & - & 747 & - & - & 747 & - & - & - & - \\
\hline & Pacitan & - & - & - & 747 & - & - & - & - & - & - & - \\
\hline & Ponorogo & - & - & - & 747 & - & - & - & - & - & - & - \\
\hline \multirow[t]{4}{*}{ Tugu } & Trenggalek & - & - & - & - & - & - & - & - & - & - & - \\
\hline & Tulungagung & - & - & - & - & - & - & 2.191 & - & - & - & - \\
\hline & Pacitan & - & - & - & - & 1.096 & - & - & - & - & - & - \\
\hline & Ponorogo & - & - & - & - & - & - & - & - & - & - & - \\
\hline \multirow[t]{4}{*}{ Pule } & Trenggalek & - & - & - & - & - & 3.663 & - & - & - & - & - \\
\hline & Tulungagung & - & - & - & - & - & 2.289 & - & - & - & - & - \\
\hline & Pacitan & - & - & - & - & - & - & - & - & - & - & 916 \\
\hline & Ponorogo & - & - & - & - & - & 916 & - & - & - & - & - \\
\hline \multirow[t]{4}{*}{ Pogalan } & Trenggalek & - & - & - & - & - & - & 5.117 & - & - & - & - \\
\hline & Tulungagung & - & - & - & - & - & - & - & - & - & - & - \\
\hline & Pacitan & - & - & - & - & - & - & - & - & - & - & - \\
\hline & Ponorogo & - & - & - & - & - & - & 2.193 & - & - & - & - \\
\hline \multirow[t]{4}{*}{ Karangan } & Trenggalek & - & - & - & - & - & - & - & - & - & - & - \\
\hline & Tulungagung & - & - & - & - & - & - & - & - & - & - & - \\
\hline & Pacitan & - & - & - & - & - & - & - & - & - & - & - \\
\hline & Ponorogo & - & - & - & - & 2.610 & - & - & - & - & - & - \\
\hline \multicolumn{2}{|c|}{ Total Dukungan Ruas } & 7.514 & 17.062 & 11.193 & 5.604 & 8.172 & 6.868 & 10.248 & 15.539 & 20.005 & 2.177 & 916 \\
\hline
\end{tabular}

Tabel 6 merupakan jumlah dukungan ruas terhadap besaran komoditas yang dialirkan melalui ruas jalan yang diteliti, dan Tabel 7 menunjukkan bagaimana ruas jalan diukur nilai ekonominya berdasarkan besaran komoditas padi yang menuju tujuan melalui ruas jalan yang diteliti. Tabel 8 merupakan total perhitungan atas dukungan ruas jalan untuk potensi komoditas unggulan di Kabupaten Trenggalek.

Tabel 7. Nilai Ruas Guna Mendukung Komoditas Padi

\begin{tabular}{llll}
\hline No. & Ruas Jalan & $\begin{array}{c}\text { Nilai } \\
\text { Komoditas } \\
\text { Padi (Ton) }\end{array}$ & $\begin{array}{c}\text { Nilai Ekonomi } \\
\text { (Rp.) }\end{array}$ \\
\hline 1 & Kedunglurah - Gandusari & 7.514 & 33.811 .200 .000 \\
\hline 2 & Gandusari - Kampak & 17.062 & 76.778 .100 .000 \\
\hline 3 & Kampak - Munjungan & 11.193 & 50.368 .500 .000 \\
\hline
\end{tabular}

\begin{tabular}{llll}
\hline No. & \multicolumn{1}{c}{ Ruas Jalan } & $\begin{array}{c}\text { Nilai } \\
\text { Komoditas } \\
\text { Padi (Ton) }\end{array}$ & $\begin{array}{c}\text { Nilai Ekonomi } \\
\text { (Rp.) }\end{array}$ \\
\hline 4 & Ngares - Bendungan & 5.604 & 25.218 .000 .000 \\
\hline 5 & Nglongsor - Karangan & 8.172 & 36.775 .350 .000 \\
\hline 6 & Suruh - Pule & 6.868 & 30.904 .875 .000 \\
\hline 7 & Bendo - Surodakan & 10.248 & 46.114 .650 .000 \\
\hline 8 & Ngetal - Gandusari & 15.539 & 69.923 .700 .000 \\
\hline 9 & Sumberingin - Kebon & 20.005 & 90.024 .300 .000 \\
\hline 10 & Pringapus -Bogoran & 2.177 & 9.795 .600 .000 \\
\hline 11 & Bangunsari - Bulu & 916 & 4.120 .650 .000 \\
\hline
\end{tabular}

Tabel 8. Nilai Ruas Jalan untuk Mendukung Potensi Komoditas Wilayah (dalam jutaan rupiah)

\begin{tabular}{|c|c|c|c|c|c|c|c|c|c|c|c|}
\hline No. & Ruas Jalan & $\begin{array}{c}\text { Nilai } \\
\text { Ekonomi } \\
\text { Padi }\end{array}$ & $\begin{array}{c}\text { Nilai } \\
\text { Ekonomi } \\
\text { Jagung }\end{array}$ & $\begin{array}{c}\text { Nilai } \\
\text { Ekonomi } \\
\text { Ubi } \\
\text { Kayu }\end{array}$ & $\begin{array}{c}\text { Nilai } \\
\text { Ekonomi } \\
\text { Kopi }\end{array}$ & $\begin{array}{c}\text { Nilai } \\
\text { Ekonomi } \\
\text { Kelapa }\end{array}$ & $\begin{array}{c}\text { Nilai } \\
\text { Ekonomi } \\
\text { Ayam } \\
\text { Potong }\end{array}$ & $\begin{array}{c}\text { Nilai } \\
\text { Ekonomi } \\
\text { Kambing }\end{array}$ & $\begin{array}{c}\text { Nilai } \\
\text { Ekonomi } \\
\text { Sapi }\end{array}$ & $\begin{array}{c}\text { Nilai } \\
\text { Ekonomi } \\
\text { Ikan } \\
\text { laut }\end{array}$ & $\begin{array}{c}\text { Total } \\
\text { Nilai } \\
\text { Ekonomi }\end{array}$ \\
\hline 1 & $\begin{array}{l}\text { Kedunglurah - } \\
\text { Gandusari }\end{array}$ & 33.811 & 4.254 & 8.665 & 681 & 109 & 4.991 & 12.095 & 8.083 & 357 & 73.046 \\
\hline 2 & Gandusari - Kampak & 76.778 & 2.884 & 13.471 & 2.443 & 3.335 & 15.143 & 31.945 & 13.042 & 2.501 & 161.543 \\
\hline 3 & Kampak - Munjungan & 50.369 & 1.438 & 11.972 & 2.303 & 2.765 & 65 & 10.092 & 3.034 & 2.501 & 84.538 \\
\hline 4 & Ngares - Bendungan & 25.218 & 16.917 & 37.115 & 379 & 801 & - & 28.049 & 46.022 & - & 154.501 \\
\hline 5 & Nglongsor - Karangan & 36.775 & 360 & 11.658 & 576 & 801 & 5.731 & - & - & - & 55.900 \\
\hline 6 & Suruh - Pule & 30.905 & 15.005 & 1.145 & 546 & 631 & 513 & 99.909 & 27.144 & - & 175.797 \\
\hline 7 & Bendo - Surodakan & 46.115 & 14.018 & 15.122 & 108 & 188 & 256 & 17.127 & 28.951 & 2.143 & 124.028 \\
\hline 8 & Ngetal - Gandusari & 69.924 & 9.793 & 27.808 & 1.350 & 2.863 & 12.385 & 31.876 & 16.826 & 2.143 & 174.968 \\
\hline 9 & Sumberingin - Kebon & 90.024 & 10.152 & 39.466 & 1.926 & 3.663 & 17.212 & 31.876 & 16.826 & - & 211.146 \\
\hline 10 & Pringapus -Bogoran & 9.796 & - & - & - & - & 2.952 & - & - & - & 12.747 \\
\hline 11 & Bangunsari - Bulu & 4.121 & - & - & - & - & 68 & - & - & - & 4.189 \\
\hline
\end{tabular}


Ruas Sumberingin-Kebon memiliki dukungan tertinggi untuk komoditas ekonomi wilayah di antara 10 (sepuluh) ruas yang lain, yaitu sebesar Rp. 211.145.908.000,00 sedangkan pada ruas BangunsariBulu memiliki nilai dukungan ruas jalan terhadap potensi komoditas terkecil yaitu sebesar Rp. 4.189.002.000,00,00.

\section{Lalu lintas Harian Rata-rata}

Lalu lintas harian rata-rata menunjukkan nilai kepentingan ruas jalan merujuk pada volume kendaraan yang melintas. Berdasarkan pada Tabel 9 maka lalu lintas harian rata-rata ruas Bendo-Surodakan memiliki nilai yang tertinggi.

Tabel 9. Nilai Lalu-lintas Harian Rata-rata

\begin{tabular}{clc}
\hline No. & \multicolumn{1}{c}{ Nama Ruas } & $\begin{array}{c}\text { Nilai } \\
\text { LHR }\end{array}$ \\
\hline 1 & Kedunglurah - Gandusari & 654 \\
\hline 2 & Gandusari - Kampak & 883 \\
\hline 3 & Kampak - Munjungan & 543 \\
\hline 4 & Ngares - Bendungan & 466 \\
\hline 5 & Nglongsor - Karangan & 956 \\
\hline 6 & Suruh - Pule & 565 \\
\hline 7 & Bendo - Surodakan & 985 \\
\hline 8 & Ngetal - Gandusari & 776 \\
\hline 9 & Sumberingin - Kebon & 663 \\
\hline 10 & Pringapus -Bogoran & 445 \\
\hline 11 & Bangunsari - Bulu & 312 \\
\hline
\end{tabular}

$\underline{\text { Jumlah Penduduk }}$

Berdasarkan Tabel 10 diketahui bahwa ruas jalan Bendo-Surodakan mendukung kebutuhan pergerakan penduduk yang diukur berdasarkan kebutuhan semua jumlah penduduk yang terdapat pada wilayah yang dilalui oleh ruas jalan.

Tabel 10. Rekapitulasi Jumlah Penduduk yang Didukung Ruas Jalan

\begin{tabular}{clc}
\hline No. & \multicolumn{1}{c}{ Ruas Jalan } & $\begin{array}{c}\text { Jumlah } \\
\text { Penduduk }\end{array}$ \\
\hline 1 & $\begin{array}{l}\text { Kedunglurah - } \\
\text { Gandusari }\end{array}$ & 33.650 \\
\hline 2 & Gandusari - Kampak & 32.047 \\
\hline 3 & Kampak - Munjungan & 27.078 \\
\hline 4 & Ngares - Bendungan & 24.611 \\
\hline 5 & Nglongsor - Karangan & 17.268 \\
\hline 6 & Suruh - Pule & 32.575 \\
\hline 7 & Bendo - Surodakan & 41.302 \\
\hline 8 & Ngetal - Gandusari & 9.025 \\
\hline 9 & Sumberingin - Kebon & 17.659 \\
\hline 10 & Pringapus -Bogoran & 25.046 \\
\hline 11 & Bangunsari - Bulu & 15.562 \\
\hline
\end{tabular}

Fasilitas

Tabel 11, 12, dan 13 menunjukkan dukungan ruas jalan terhadap keberadaan fungsi fasilitas kesehatan, fasilitas pemerintahan dan fasilitas pendidikan, berdasarkan ketiga hasil ini maka pada Tabel 14 diketahui bahwa ruas jalan Kampak-Munjungan memiliki dukungan atas fasilitas yang tertinggi dari 10 (sepuluh ruas) jalan yang lain dalam melayani pergerakan penduduk menuju fasilitas publik.

Tabel 11. Dukungan Ruas untuk Fasilitas Kesehatan

\begin{tabular}{|c|c|c|c|c|c|c|c|c|c|c|c|c|}
\hline \multirow{2}{*}{ Fasilitas } & \multirow{2}{*}{$\begin{array}{c}\text { Jumlah } \\
\text { Kunjungan }\end{array}$} & \multicolumn{11}{|c|}{ Jumlah pergerakan orang fasilitas kesehatan melalui ruas } \\
\hline & & 1 & 2 & 3 & 4 & 5 & 6 & 7 & 8 & 9 & 10 & 11 \\
\hline Puskesmas Suruh & 11.642 & - & - & - & - & - & 11.642 & - & - & - & - & - \\
\hline Puskesmas Kampak & 11.848 & - & 11.848 & - & - & - & - & - & - & - & - & - \\
\hline Puskesmas Karanganyar & 8.013 & 8.013 & - & - & - & - & - & - & - & - & - & - \\
\hline Puskesmas Karangan & 29.500 & - & - & - & - & 29.500 & - & - & - & - & - & - \\
\hline Puskesmas Munjungan & 31.124 & - & - & 31.124 & - & - & - & - & - & - & - & - \\
\hline Puskesmas Pule & 18.137 & - & - & - & - & - & 18.137 & - & - & - & - & - \\
\hline Puskesmas Rejowinangun & 22.515 & - & - & - & - & - & - & 22.515 & - & - & - & - \\
\hline Puskesmas Bendungan & 12.538 & - & - & - & 12.538 & - & - & - & - & - & - & - \\
\hline Total Dukungaı & uas & 8.013 & 11.848 & 31.124 & 12.538 & 29.500 & 29.779 & 22.515 & - & - & - & - \\
\hline
\end{tabular}

Tabel 12. Dukungan Ruas untuk Fasilitas Pemerintahan

\begin{tabular}{|c|c|c|c|c|c|c|c|c|c|c|c|}
\hline \multirow[b]{2}{*}{ Fasilitas } & \multicolumn{11}{|c|}{ Jumlah pergerakan orang mengurus KTP dan administrasi lainnya } \\
\hline & 1 & 2 & 3 & 4 & 5 & 6 & 7 & 8 & 9 & 10 & 11 \\
\hline Kantor Desa Sukorame & 1.311 & - & - & - & - & - & - & - & - & - & - \\
\hline Kantor Desa Melis & 1.000 & - & - & - & - & - & - & - & - & - & - \\
\hline Kantor Desa Karanganyar & 435 & - & - & - & - & - & - & - & - & - & - \\
\hline Kantor Desa Ganduari & 2.535 & - & - & - & - & - & - & - & - & - & - \\
\hline Kecamatan Gandusari & 18.904 & - & - & - & - & - & - & - & - & - & - \\
\hline Kantor Desa Wonorejo & - & 1.955 & - & - & - & - & - & - & - & - & - \\
\hline Kantor Desa Ngrayung & - & 918 & - & - & - & - & - & - & - & - & - \\
\hline Kantor Desa Sugihan & - & 1.395 & - & - & - & - & - & - & - & - & - \\
\hline Kantor Desa Bendoagung & - & 1.371 & - & - & - & - & - & - & - & - & - \\
\hline $\begin{array}{l}\text { Kantor Kecamatan } \\
\text { Kampak }\end{array}$ & - & 13.424 & - & - & - & - & - & - & - & - & - \\
\hline Kantor Desa Ngadimulyo & - & - & 1.384 & - & - & - & - & - & - & - & - \\
\hline Kantor Desa Besuki & - & - & 1.214 & - & - & - & - & - & - & - & - \\
\hline Kantor Desa Karangturi & - & - & 2.112 & - & - & - & - & - & - & - & - \\
\hline
\end{tabular}


Jumlah pergerakan orang mengurus KTP dan administrasi lainnya

\begin{tabular}{|c|c|c|c|c|c|c|c|c|c|c|c|}
\hline Fasilitas & 1 & 2 & 3 & 4 & 5 & 6 & 7 & 8 & 9 & 10 & 11 \\
\hline Kantor Desa Munjungan & - & - & 2.538 & - & - & - & - & - & - & - & - \\
\hline Kecamatan Munjungan & - & - & 18.583 & - & - & - & - & - & - & - & - \\
\hline Kantor Desa Ngares & - & - & - & 1.596 & - & - & - & - & - & - & - \\
\hline Kantor Desa Srabah & - & - & - & 491 & - & - & - & - & - & - & - \\
\hline Kantor Desa Sumurup & - & - & - & 2.064 & - & - & - & - & - & - & - \\
\hline Kantor Desa Surenlor & - & - & - & 644 & - & - & - & - & - & - & - \\
\hline $\begin{array}{l}\text { Kantor Kecamatan } \\
\text { Bendungan }\end{array}$ & - & - & - & 9.770 & - & - & - & - & - & - & - \\
\hline Kantor Desa Kerjo & - & - & - & - & 986 & - & - & - & - & - & - \\
\hline Kantor Desa Nglongsor & - & - & - & - & 1.668 & - & - & - & - & - & - \\
\hline Kantor Desa Suruh & - & - & - & - & - & 1.757 & - & - & - & - & - \\
\hline Kantor Desa Gamping & - & - & - & - & - & 1.561 & - & - & - & - & - \\
\hline Kantor Desa Jombok & - & - & - & - & - & 3.410 & - & - & - & - & - \\
\hline Kantor Kecamatan Suruh & - & - & - & - & - & 3.740 & - & - & - & - & - \\
\hline Kantor Desa Sumberingin & - & - & - & - & - & - & - & - & 2.329 & - & - \\
\hline Kantor Desa Jatiprahu & - & - & - & - & - & - & - & - & 1.841 & - & - \\
\hline Kantor Desa Wonoanti & - & - & - & - & - & - & - & - & 1.658 & - & - \\
\hline Kantor Desa Bendorejo & - & - & - & - & - & & 3.098 & - & - & - & - \\
\hline Kantor Desa Gembleb & - & - & - & - & - & & 1.978 & - & - & - & - \\
\hline Kantor Desa Ngadirenggo & - & - & - & - & - & & 2.612 & - & - & - & - \\
\hline $\begin{array}{l}\text { Kantor Desa } \\
\text { Rejowinangun }\end{array}$ & - & - & - & - & - & & 1.088 & - & - & - & - \\
\hline Kantor Desa Pogalan & - & - & - & - & - & & 2.059 & - & - & - & - \\
\hline Kantor Desa Surodakan & - & - & - & - & - & & 1.101 & - & - & - & - \\
\hline Kantor Desa Ngetal & - & - & - & - & - & - & - & 958 & - & - & - \\
\hline Kantor Desa Wonocoyo & - & - & - & - & - & - & - & 1.398 & - & - & - \\
\hline Kantor Desa Dongko & - & - & - & - & - & - & - & - & - & - & 3.996 \\
\hline Kantor Desa Pakel & - & - & - & - & - & - & - & - & - & - & 1.139 \\
\hline Kantor Desa Pule & - & - & - & - & - & - & - & - & - & - & 4.021 \\
\hline Kantor Desa Pringapus & - & - & - & - & - & - & - & - & - & 2.140 & - \\
\hline Total Dukungan Ruas & 24.186 & 19.063 & 25.830 & 14.566 & 2.655 & 10.468 & 11.936 & 2.356 & 5.827 & 2.140 & 9.157 \\
\hline
\end{tabular}

Tabel 13. Dukungan Ruas untuk Fasilitas Pendidikan

\begin{tabular}{|c|c|c|c|c|c|c|c|c|c|c|c|c|}
\hline \multirow[b]{2}{*}{ Fasilitas } & \multirow[b]{2}{*}{$\begin{array}{l}\text { Jumlah } \\
\text { Murid }\end{array}$} & \multicolumn{11}{|c|}{ Jumlah pergerakan orang fasilitas pendidikan } \\
\hline & & 1 & 2 & 3 & 4 & 5 & 6 & 7 & 8 & 9 & 10 & 11 \\
\hline SD Negeri 1 Suruh & 85 & - & 85 & - & - & - & - & - & - & - & - & - \\
\hline SD Negeri 2 Suruh & 77 & - & - & - & - & - & - & - & - & - & - & 77 \\
\hline SMK Suruh & 202 & - & & - & - & - & 202 & - & - & - & - & - \\
\hline SMP Negeri 1 Suruh & 150 & - & 150 & - & - & - & 150 & - & - & - & - & - \\
\hline MI. Sugihan & 66 & - & 66 & - & - & - & - & - & - & - & - & - \\
\hline MTsN Kampak & 220 & - & 220 & - & - & - & - & - & - & - & - & - \\
\hline SDN 1 Ngadimulyo & 67 & - & - & 67 & - & - & - & - & - & - & - & - \\
\hline SDN 1 Bogoran & 78 & - & - & - & - & - & - & - & - & - & 78 & - \\
\hline SDN 1 Sugihan & 81 & - & - & - & - & - & - & - & - & 81 & - & - \\
\hline SDN 3 Bogoran & 85 & - & - & - & - & - & - & - & - & - & 85 & - \\
\hline SMAN 1 Kampak & 231 & - & - & 231 & - & - & - & - & - & - & - & - \\
\hline MI. Gumelar & 65 & - & - & - & - & - & - & - & - & - & 65 & - \\
\hline MI. Miftahul Huda & 66 & - & - & - & - & - & - & - & - & - & 66 & - \\
\hline MI. Nurul Huda & 88 & - & - & - & - & - & - & - & 88 & - & - & - \\
\hline MTs Muhamadiyah & 224 & - & - & - & - & - & - & - & 224 & - & - & - \\
\hline SD Murul Fikri + Masjid & 105 & - & - & - & - & - & - & - & 105 & - & - & - \\
\hline SDN 01 Gandusari & 99 & 99 & - & - & - & - & - & - & - & - & - & - \\
\hline SDN 01 Karang Anyar & 90 & 90 & - & - & - & - & - & - & - & - & - & - \\
\hline SDN 01 Melis & 80 & 80 & - & - & - & - & - & - & - & - & - & - \\
\hline SDN 01 Ngrayong & 88 & - & 88 & - & - & - & - & - & - & - & - & - \\
\hline SDN 01 Sukarame & 85 & 85 & - & - & - & - & - & - & - & - & - & - \\
\hline SDN 01 Widoro & 81 & 81 & - & - & - & - & - & - & - & - & - & - \\
\hline SDN 01 Wonoanti & 82 & 82 & - & - & - & - & - & - & - & - & - & - \\
\hline SDN 02 Karang Anyar & 83 & 83 & - & - & - & - & - & - & - & - & - & - \\
\hline SDN 03 Sukarame & 81 & - & - & - & - & - & - & - & - & 81 & - & - \\
\hline SDN 1 Pringapus & 76 & - & - & - & - & - & - & - & - & - & 76 & - \\
\hline SDN 1 Wates & 87 & - & - & - & - & - & - & - & - & 87 & - & - \\
\hline SDN 2 Dongko & 82 & - & - & - & - & - & - & - & 82 & - & - & - \\
\hline MI 2 Munjungan & 85 & - & - & 85 & - & - & - & - & - & - & - & - \\
\hline MI Besuki & 77 & - & - & 77 & - & - & - & - & - & - & - & - \\
\hline SD Kusuma Bangsa & 90 & - & - & - & - & - & - & - & 90 & - & - & - \\
\hline SDN 1 Besuki & 93 & - & - & 93 & - & - & - & - & - & - & - & - \\
\hline SDN 1-2 Karangturi & 77 & - & - & 77 & - & - & - & - & - & - & - & - \\
\hline SDN 2 Besuki & 72 & - & - & 72 & - & - & - & - & - & - & - & - \\
\hline
\end{tabular}




\begin{tabular}{|c|c|c|c|c|c|c|c|c|c|c|c|c|}
\hline \multirow[b]{3}{*}{ Fasilitas } & \multirow[b]{3}{*}{$\begin{array}{c}\text { Jumlah } \\
\text { Murid }\end{array}$} & \multirow{2}{*}{\multicolumn{11}{|c|}{ Jumlah pergerakan orang fasilitas pendidikan }} \\
\hline & & & & & & & & & & & & \\
\hline & & 1 & 2 & 3 & 4 & 5 & 6 & 7 & 8 & 9 & 10 & 11 \\
\hline SDN 2 Munjungan & 68 & - & - & 68 & - & - & - & - & - & - & - & - \\
\hline SDN 3 Besuki & 82 & - & - & 82 & - & - & - & - & - & - & - & - \\
\hline SDN 3 Besuki & 84 & - & - & 84 & - & - & - & - & - & - & - & - \\
\hline SDN 3 Karangturi & 77 & - & - & 77 & - & - & - & - & - & - & - & - \\
\hline SDN I Munjugan & 76 & - & - & 76 & - & - & - & - & - & - & - & - \\
\hline SMAN I Pule & 254 & - & - & - & - & - & 254 & - & - & - & - & - \\
\hline SMP Islam Pule & 215 & - & - & - & - & - & 215 & - & - & - & - & - \\
\hline SMPN I Pule & 210 & - & - & - & - & - & 210 & - & - & - & - & - \\
\hline SDN 01 Rejowinangun & 78 & - & - & - & - & - & - & 78 & - & - & - & - \\
\hline SDN 02 Nglongsor & 84 & - & - & - & - & 84 & - & - & - & - & - & - \\
\hline SMPN 2 Tugu & 201 & - & - & - & - & 201 & - & - & - & - & - & - \\
\hline SDN 5 Bendorejo & 77 & - & - & - & - & - & - & 77 & - & - & - & - \\
\hline SMKN Pogalan & 287 & - & - & - & - & - & - & 287 & - & - & - & - \\
\hline SMPN 1 Pogalan & 220 & - & - & - & - & - & - & 220 & - & - & - & - \\
\hline SDN 01 Ngares & 78 & - & - & - & 78 & - & - & - & - & - & - & - \\
\hline SDN 03 Srabah & 81 & - & - & - & 81 & - & - & - & - & - & - & - \\
\hline SDN 2 Sumurup & 90 & - & - & - & 90 & - & - & - & - & - & - & - \\
\hline SDN 3 Sumurup & 71 & - & - & - & 71 & - & - & - & - & - & - & - \\
\hline SDN 3 Surenlor & 67 & - & - & - & 67 & - & - & - & - & - & - & - \\
\hline SDN 4 Dompyong & 77 & - & - & - & 77 & - & - & - & - & - & - & - \\
\hline SDN I Sumurup & 84 & - & - & - & 84 & - & - & - & - & - & - & - \\
\hline SMAN I Bendungan & 206 & - & - & - & 206 & - & - & - & - & - & - & - \\
\hline SMP I Bendungan & 220 & - & - & - & 220 & - & - & - & - & - & - & - \\
\hline \multicolumn{2}{|c|}{ Total Dukungan Ruas } & 600 & 609 & 1.089 & 974 & 285 & $\mathbf{1 . 0 3 1}$ & 662 & 589 & 249 & 370 & 77 \\
\hline
\end{tabular}

Tabel 14. Rekapitulasi Dukungan Jalan untuk Fasilitas Publik

\begin{tabular}{clcccc}
\hline No. & Ruas Jalan & $\begin{array}{c}\text { Fasilitas } \\
\text { Kesehatan } \\
\text { (Jiwa) }\end{array}$ & $\begin{array}{c}\text { Fasilitas } \\
\text { Pendidikan } \\
\text { (Jiwa) }\end{array}$ & $\begin{array}{c}\text { Fasilitas } \\
\text { Pemerintahan } \\
\text { (Jiwa) }\end{array}$ & Jumlah \\
\hline 1 & Kedunglurah - Gandusari & 8.013 & 600 & 24.186 & 32.799 \\
\hline 2 & Gandusari - Kampak & 11.848 & 609 & 19.063 & 31.520 \\
\hline 3 & Kampak - Munjungan & 31.124 & 609 & 25.830 & 57.563 \\
\hline 4 & Ngares - Bendungan & 12.538 & 974 & 14.566 & 28.078 \\
\hline 5 & Nglongsor - Karangan & 29.500 & 285 & 2.655 & 32.440 \\
\hline 6 & Suruh - Pule & 29.779 & 1.031 & 10.468 & 41.278 \\
\hline 7 & Bendo - Surodakan & 22.515 & 662 & 11.936 & 35.113 \\
\hline 8 & Ngetal - Gandusari & - & 589 & 2.356 & 2.945 \\
\hline 9 & Sumberingin - Kebon & - & 249 & 5.827 & 6.076 \\
\hline 10 & Pringapus -Bogoran & - & 370 & 2.140 & 2.510 \\
\hline 11 & Bangunsari - Bulu & - & 77 & 9.157 & 9.234 \\
\hline
\end{tabular}

Hirarki Ruas terhadap perwilayahan perkotaan

Tabel 15 menunjukkan penilaian keterhubungan ruas jalan mendukung hirarki perwilayahan, yang menghasilkan nilai tertinggi pada ruas Ngares Bendungan dan ruas Bendo - Surodakan. Kedua ruas ini menghubungkan pusat kecamatan ke ibukota kabupaten.

Tabel 15. Hirarki Ruas Jalan berdasar Perwilayahan Perkotaan

\begin{tabular}{clc}
\hline $\begin{array}{c}\text { No. } \\
\text { urut }\end{array}$ & \multicolumn{1}{c}{ Ruas Jalan } & $\begin{array}{c}\text { Nilai Hirarki } \\
\text { Ruas }\end{array}$ \\
\hline 1 & Kedunglurah - Gandusari & 4 \\
\hline 2 & Gandusari - Kampak & 3 \\
\hline 3 & Kampak - Munjungan & 3 \\
\hline 4 & Ngares - Bendungan & 5 \\
\hline 5 & Nglongsor - Karangan & 3 \\
\hline 6 & Suruh - Pule & 2 \\
\hline 7 & Bendo - Surodakan & 5 \\
\hline 8 & Ngetal - Gandusari & 3 \\
\hline 9 & Sumberingin - Kebon & 3 \\
\hline 10 & Pringapus -Bogoran & 3 \\
\hline 11 & Bangunsari - Bulu & 2 \\
\hline
\end{tabular}

\section{Kondisi Ruas}

Dari Tabel 16 diketahui terdapat 3 (tiga) ruas jalan yang memiliki kondisi jalan yang rusak berat yaitu pada ruas Kampak-Munjungan, Pringapus-Bogoran dan ruas Bangunsari-Bulu.
Tabel 16. Kondisi Ruas Jalan

\begin{tabular}{clcc}
\hline \multirow{2}{*}{ No. } & \multirow{2}{*}{ Nama Ruas } & \multicolumn{2}{c}{ Kondisi } \\
\cline { 3 - 4 } & & Kondisi & Nilai \\
\hline 1 & Kedunglurah - Gandusari & RR & 3 \\
\hline 2 & Gandusari - Kampak & RR & 3 \\
\hline 3 & Kampak - Munjungan & RB & 4 \\
\hline 4 & Ngares - Bendungan & RR & 3 \\
\hline 5 & Nglongsor - Karangan & S & 2 \\
\hline 6 & Suruh - Pule & S & 2 \\
\hline 7 & Bendo - Surodakan & S & 2 \\
\hline 8 & Ngetal - Gandusari & RR & 3 \\
\hline 9 & Sumberingin - Kebon & RR & 3 \\
\hline 10 & Pringapus -Bogoran & RB & 4 \\
\hline 11 & Bangunsari - Bulu & RB & 4 \\
\hline & & &
\end{tabular}

\section{Rangking Prioritas Ruas Jalan Kabupaten Poros Antar Kecamatan}

Untuk mengukur nilai preferensi pada masingmasing ruas jalan menggunakan TOPSIS, langkahlangkah yang dilakukan dijelaskan di bawah ini [4],

1. Menyusun matriks keputusan alternatif

Menyusun matriks a $\mathrm{x} \mathrm{k}$, didasarkan pada nilai data eksisting kriteria untuk masing-masing alternatif. Matriks keputusan disajikan dalam Tabel 17 di bawah ini. 
Tabel 17. Matriks Keputusan

\begin{tabular}{|c|c|c|c|c|c|c|c|}
\hline \multirow{2}{*}{ No. } & \multirow{2}{*}{ Alternatif } & \multicolumn{6}{|c|}{ Kriteria } \\
\hline & & PE & LH & SP & FS & HR & KR \\
\hline 1 & Kedunglurah - Gandusari & 73.045 .845 .000 & 654 & 33.650 & 32.799 & 4 & 3 \\
\hline 2 & Gandusari - Kampak & 161.542 .827 .000 & 883 & 32.047 & 31.520 & 3 & 3 \\
\hline 3 & Kampak - Munjungan & 84.538 .103 .000 & 543 & 27.078 & 57.563 & 3 & 4 \\
\hline 4 & Ngares - Bendungan & 154.500 .880 .000 & 466 & 24.611 & 28.078 & 5 & 3 \\
\hline 5 & Nglongsor - Karangan & 55.900 .386 .000 & 956 & 17.268 & 32.440 & 3 & 2 \\
\hline 6 & Suruh - Pule & 175.797 .315 .000 & 565 & 32.575 & 41.278 & 2 & 2 \\
\hline 7 & Bendo - Surodakan & 124.028 .305 .000 & 985 & 41.302 & 35.113 & 5 & 2 \\
\hline 8 & Ngetal - Gandusari & 174.967 .546 .000 & 776 & 9.025 & 2.945 & 3 & 3 \\
\hline 9 & Sumberingin - Kebon & 211.145 .908 .000 & 663 & 17.659 & 6.076 & 3 & 3 \\
\hline 10 & Pringapus -Bogoran & 12.747 .352 .000 & 445 & 25.046 & 2.510 & 3 & 4 \\
\hline 11 & Bangunsari - Bulu & 4.189 .002 .000 & 312 & 15.562 & 9.234 & 2 & 4 \\
\hline
\end{tabular}

Tabel 18. Matriks Keputusan ternormalisasi

\begin{tabular}{llcccccc}
\hline \multirow{2}{*}{ No. } & \multirow{2}{*}{ Alternatif } & $\mathbf{4 3 2 . 7 0 9 . 8 8 2 . 1 4 1 , 6 4}$ & $\mathbf{2 . 2 9 3}$ & $\mathbf{8 8 4 6 6}$ & $\mathbf{1 0 1 4 7 6 , 4 9 9}$ & $\mathbf{1 1 , 3 1 3 7 0 8 5}$ & $\mathbf{1 0 , 2 4 6 9 5 0 8}$ \\
\cline { 3 - 8 } & & $\mathbf{P E}$ & $\mathbf{L H}$ & $\mathbf{S P}$ & $\mathbf{F S}$ & $\mathbf{H R}$ & $\mathbf{K R}$ \\
\hline 1 & Kedunglurah - Gandusari & 0,17 & 0,29 & 0,38 & 0,32 & 0,35 & 0,29 \\
\hline 2 & Gandusari - Kampak & 0,37 & 0,39 & 0,36 & 0,31 & 0,27 & 0,29 \\
\hline 3 & Kampak - Munjungan & 0,20 & 0,24 & 0,31 & 0,57 & 0,27 & 0,39 \\
\hline 4 & Ngares - Bendungan & 0,36 & 0,20 & 0,28 & 0,28 & 0,44 & 0,29 \\
\hline 5 & Nglongsor - Karangan & 0,13 & 0,42 & 0,20 & 0,32 & 0,27 & 0,20 \\
\hline 6 & Suruh - Pule & 0,41 & 0,25 & 0,37 & 0,41 & 0,18 & 0,20 \\
\hline 7 & Bendo - Surodakan & 0,29 & 0,43 & 0,47 & 0,35 & 0,44 & 0,20 \\
\hline 8 & Ngetal - Gandusari & 0,40 & 0,34 & 0,10 & 0,03 & 0,27 \\
\hline 9 & Sumberingin - Kebon & 0,49 & 0,29 & 0,20 & 0,06 & 0,27 & 0,29 \\
\hline 10 & Pringapus - Bogoran & 0,03 & 0,19 & 0,28 & 0,02 & 0,27 \\
\hline 11 & Bangunsari - Bulu & 0,01 & 0,14 & 0,18 & 0,09 & 0,18 \\
\hline
\end{tabular}

Tabel 19. Matriks Keputusan ternormalisasi terbobot

\begin{tabular}{|c|c|c|c|c|c|c|c|}
\hline \multirow{3}{*}{ No. } & \multirow{3}{*}{$\frac{\text { Bobot }}{\text { Alternatif }}$} & 0,2017 & 0,2406 & 0,0914 & $\mathbf{0 , 0 3 9 3}$ & 0,0468 & 0,3802 \\
\hline & & \multicolumn{6}{|c|}{ Kriteria } \\
\hline & & $\mathbf{P E}$ & $\mathbf{L H}$ & SP & FS & HR & KR \\
\hline 1 & Kedunglurah - Gandusari & 0,03406 & 0,06861 & 0,03476 & 0,01271 & 0,01654 & 0,11131 \\
\hline 2 & Gandusari - Kampak & 0,07532 & 0,09263 & 0,03310 & 0,01221 & 0,01241 & 0,11131 \\
\hline 3 & Kampak - Munjungan & 0,03941 & 0,05696 & 0,02797 & 0,02230 & 0,01241 & 0,14841 \\
\hline 4 & Ngares - Bendungan & 0,07203 & 0,04888 & 0,02542 & 0,01088 & 0,02068 & 0,11131 \\
\hline 5 & Nglongsor - Karangan & 0,02606 & 0,10029 & 0,01784 & 0,01257 & 0,01241 & 0,07420 \\
\hline 6 & Suruh - Pule & 0,08196 & 0,05927 & 0,03365 & 0,01599 & 0,00827 & 0,07420 \\
\hline 7 & Bendo - Surodakan & 0,05783 & 0,10333 & 0,04266 & 0,01360 & 0,02068 & 0,07420 \\
\hline 8 & Ngetal - Gandusari & 0,08158 & 0,08140 & 0,00932 & 0,00114 & 0,01241 & 0,11131 \\
\hline 9 & Sumberingin - Kebon & 0,09844 & 0,06955 & 0,01824 & 0,00235 & 0,01241 & 0,11131 \\
\hline 10 & Pringapus -Bogoran & 0,00594 & 0,04668 & 0,02587 & 0,00097 & 0,01241 & 0,14841 \\
\hline 11 & Bangunsari - Bulu & 0,00195 & 0,03273 & 0,01607 & 0,00358 & 0,00827 & 0,14841 \\
\hline
\end{tabular}

1. Menyusun matriks keputusan ternormalisasi Menyusun matriks keputusan ternormalisasi pada masing-masing elemen matriks keputusan dengan rumus $r_{\mathrm{i} j}=\frac{x_{\mathrm{if}^{j}}}{\sqrt{\sum_{\mathrm{i}=1}^{* 1} x_{\mathrm{if}}^{2}}}$ sebagaimana ditampilkan dalam Tabel 18 .

2. Menyusun matriks keputusan ternormalisasi terbobot

Menyusun matriks dengan hasil perkalian elemen matriks ternormalisasi dengan input bobot yang merupakan hasil dari matriks perbandingan berpasangan, lih. Tabel 3. Dengan rumus pada tiap elemen $V_{i j}$ adalah : $w_{j} r_{\mathrm{i} j}$. Matriks keputusan ternormalisasi terbobot ditunjukkan pada Tabel 19 di bawah ini.

3. Menentukan solusi ideal positif dan solusi ideal negatif

Solusi ideal positif untuk tiap-tiap kriteria didapatkan nilai $\mathrm{a}^{+}=0,09844 ; 0,10333 ; 0,04266$; 0,02230; 0,02068; 0,07420, sedangkan untuk solusi ideal negatif didapatkan nilai $\mathrm{a}^{-}=0,00195 ; 0,03273$; 0,00932; 0,00097; 0,00827; dan 0,14841. 
4. Menghitung jarak preferensi relatif

Jarak preferensi relatif didapatkan dengan menghitung jarak antara nilai setiap alternatif dengan matriks solusi ideal positif dan matriks solusi ideal negatif. Untuk menghitung jarak terhadap solusi ideal positif rumus $S_{i}^{+}=\sqrt{\sum_{j=1}^{n}\left(y_{i j}-y_{1}^{+}\right)^{2}}$, sedangkan untuk mengitung jarak terhadap solusi ideal negatif $S_{i}^{-}=\sqrt{\sum_{j=1}^{n}\left(y_{i j}-y_{i}^{-}\right)^{2}}$. Nilai jarak preferensi terhadap solusi ideal positif menghasilkan nilai berurutan dari alternatif 1 sampai dengan 11 sebagai berikut: 0,08306; 0,$04783 ; 0,10689 ; 0,07393 ; 0,07764 ; 0,04988$; 0,$04154 ; 0,06140 ; 0,05984 ; 0,13445$; dan 0,14496 , sedangkan untuk jarak preferensi terhadap solusi ideal negatif menghasilkan 0,$06743 ; 0,10515$; 0,$05301 ; 0,08402 ; 0,10429 ; 0,11589 ; 0,12263$; 0,$10051 ; 0,11019 ; 0,02240$; dan 0,00724.

5. Menghitung jarak relatif terhadap solusi ideal Jarak terdekat terhadap solusi ideal positif dan terjauh dengan solusi ideal negatif diperoleh dengan rumus, $C_{i}=\frac{s_{i}^{-}}{S_{i}^{-}+s_{i}^{+}}$, dengan nilai $C_{i}$ yang diperoleh dari alternatif 1 sampai dengan 11 , yaitu 0,$88 ; 2,30 ; 0,55 ; 1,22 ; 1,45 ; 2,44 ; 3,07 ; 1,74$; 1,$95 ; 0,19$; dan 0,06 .

6. Menentukan rangking preferensi alternatif Urutan preferensi diperoleh berdasarkan nilai $C_{i}$ yang diperoleh dengan mengurutkan berdasarkan nilai terbaik dari masing-masing alternatif, 3,07; 2,$44 ; 2,30 ; 1,95 ; 1,74 ; 1,45 ; 1,22 ; 0,88 ; 0,55 ; 0,19$; 0,06, sehingga urutan terbaik diperoleh

$C_{7}>C_{6}>C_{2}>C_{9}>C_{8}>C_{5}>C_{4}>C_{1}>C_{3}>C_{10}>C_{11}$

Berdasarkan hasil perhitungan di atas maka urutan ruas jalan poros antar kecamatan di Kabupaten ditunjukkan pada gambar 2 di bawah ini,

\section{KESIMPULAN}

Kriteria penilaian ruas jalan kabupaten poros antar kecamatan yang merupakan hasil penilaian expert adalah kriteria potensi ekonomi wilayah, lalu lintas harian ratarata, jumlah penduduk, fasilitas, hirarki, dan kondisi ruas jalan. Kriteria kondisi jalan mempunyai bobot kepentingan yang paling besar sebesar 38,02\% kemudian diikuti kriteria lalu lintas harian rata-rata sebesar $24,06 \%$. Berdasarkan penilaian data eksisting untuk 6 (enam) kriteria terpilih untuk masing-masing ruas didapatkan hasil peringkat ruas yang bervariasi di antara 11 (sebelas) ruas yang diteliti, sehingga tidak mutlak salah satu ruas dapat mencapai nilai tertinggi untuk keenam kriteria. Ruas Jalan Bendo-Surodakan terpilih sebagai prioritas

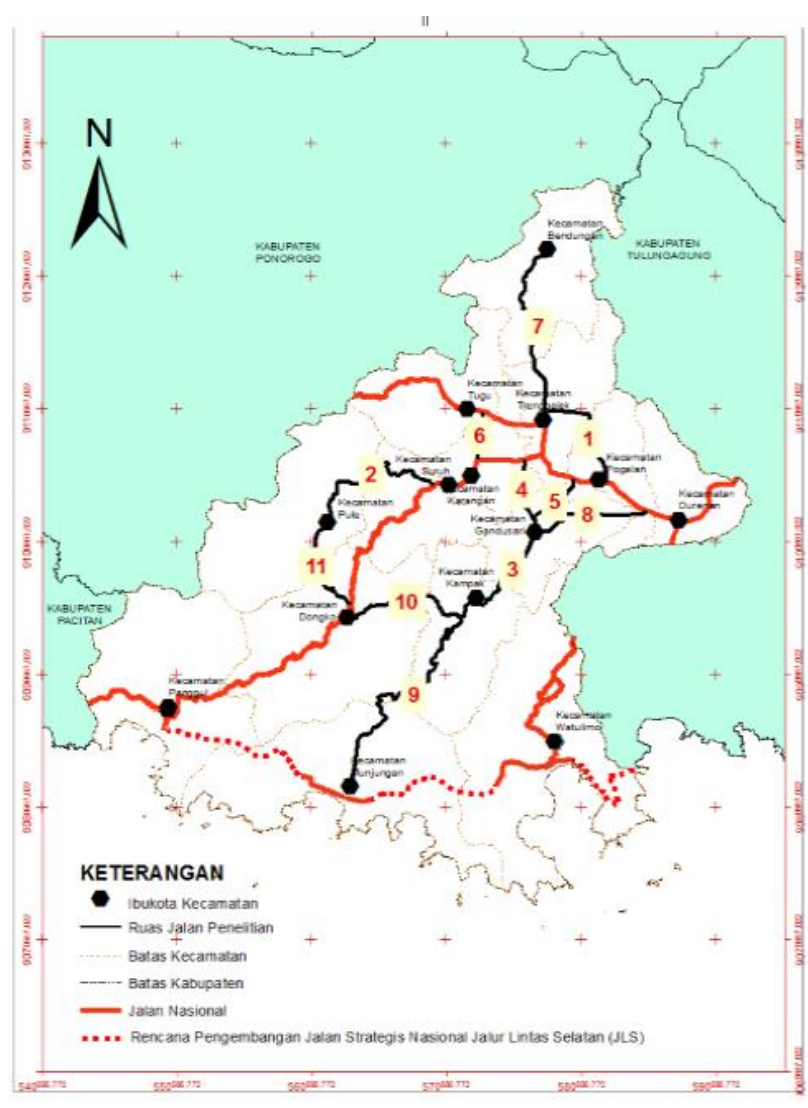

Gambar 2. Urutan Prioritas bagi Jalan Poros Antar

pertama dengan nilai preferensi 3,07, ruas ini harus dijaga kualitas layanannya agar menjadi pendorong berkembangnya wilayah-wilayah yang potensial. Ruas Suruh-Pule merupakan alternatif kedua dengan nilai preferensi sebesar 2,44, diikuti ruas Gandusari-Kampak dengan nilai preferensi 2,30. Sedangkan ruas jalan poros antarkecamatan yang merupakan alternatif terakhir dari 11(sebelas) ruas yang dikaji adalah ruas Bangunsari-Bulu dengan nilai preferensi 0,057 .

CATATAN. Makalah ini merupakan bagian dari Tesis Magister Manajemen Aset Infrastruktur, Departemen Teknik Sipil ITS Surabaya.

\section{DAFTAR PUSTAKA}

[1] Adisasmita, Sakti Adji (2011), "Transportasi dan Pengembangan Wilayah". Penerbit Graha Ilmu, Yogyakarta.

[2] Anwar, A. (2005), "Ketimpangan Pembangunan Wilayah dan Pedesaan, Tinjauan Kritis”. P4W Press, Bogor

[3] Saaty, Thomas L. (1991), "Pengambilan Keputusan bagi Para Pemimpin: Proses Hierarki Analitik untuk Pengambilan Keputusan dalam Situasi yang Kompleks". Pustaka Binaman Pressindo, Jakarta.

[4] Kusumadewi, Sri, et al (2006), "Fuzzy MultiAttribute Decision Making (Fuzzy MADM)". Penerbit Graha Ilmu, Yogyakarta. 